\title{
Good Corporate Governance for Private Multi National Company to Comply with Global Anti-Bribery Regulation (UK Bribery Act \& FCPA) and Indonesia Company Law
}

\author{
${ }^{1}$ Yayan Hernayanto \\ Legal Head Manufacturing Industry \\ Jakarta, Indonesia \\ Yayan.hernayanto@gmail.com
}

\begin{abstract}
The world of business today have a tendency to improve towards to a better condition. The spirit of changing become a company which have integrity should be supported by government policies related to bureaucratic and licensing services. Mutual benefit among Business actor and government will lead to the final goal of each party. Company will be significantly growth and expanding their business without being afraid with long bureaucratic and how many permissions to be done. For government advantage, they will generate income for government as well as employee or society. Many large companies which have affiliated with Indonesian Multi-national Company shall comply with local regulation as well as their home state regulation. The presence of $U K$ Bribery Act and FCPA US, became the new standard of Compliance management in Indonesia. What is the correlation between Global AntiBribery Regulations with Indonesia Private Liability Company Law (UU Perseroan Terbatas), Is there any risk for the directors who do not comply with the international compliance rules? And what are the activities of Indonesia Multi-National Company for facing global compliance more over after the Supreme Court released Regulation No. 13 year 2016 regarding Procedures for the Settlement of Criminal Acts Committed by Corporations.
\end{abstract}

Keywords-integrity; bureaucratic; Multi-national Company; Anti-Bribery; Company Law.

\section{INTRODUCTION}

The world of business today is improving towards a better condition, as well as for Indonesia. Indonesia's government, under the leadership of President Joko Widodo ("Jokowi"), introduce the Nawa Cita1 ("Sembilan Cita-Cita/Agenda")

Which one of them is building clean, effective, democratic, and reliable governance with priority to restore public trust to public institution.

\author{
${ }^{2}$ Santi Hapsari Dewi \\ Lecture faculty of Law Padjadjaran University \\ Bandung, Indonesia \\ Santidewina@gmail.com
}

Indonesia is striving to improve its business improvement, and one of them is through actions against corruption. As you can see the Corruption Perception Index (CPI $)^{2}$ chart provided by Transparency International below, Indonesia's

CPI score is increasing every year.

Indonesia Corruption Perception Index 2012 - 2016

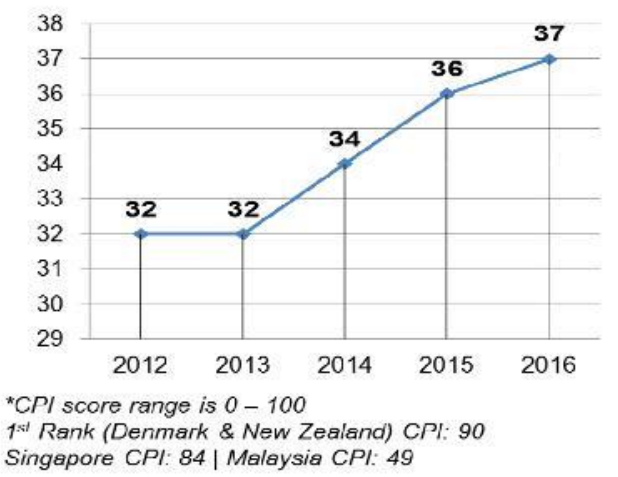

Our rank also, being compared to neighboring countries, is improving every year.

\begin{tabular}{|c|c|c|c|c|c|}
\multicolumn{6}{|c|}{ Rank Comparison to Nearby Countries } \\
\hline & 2012 & 2013 & 2014 & 2015 & 2016 \\
\hline SGP & 5 & 5 & 7 & 7 & 7 \\
\hline MYS & 54 & 53 & 51 & 54 & 55 \\
\hline INA & 118 & 114 & 107 & 88 & 90 \\
\hline THA & 88 & 102 & 85 & 76 & 101 \\
\hline PHL & 105 & 94 & 85 & 95 & 101 \\
\hline VNM & 123 & 116 & 119 & 111 & 113 \\
\hline MMR & 172 & 157 & 156 & 147 & 136 \\
\hline \multicolumn{7}{|c|}{ Source: Transparency /niemational e.V. }
\end{tabular}


As you can see that in 2012, we were below Thailand and Philippines, but in 2016 we are above them.

Such spirit of improvement is cooperation between Government and Business actors in supporting each other for mutual benefit. Government support the business though their policies and facilities given to Business actors, and also by simplifying bureaucratic process and licensing services.

For example, through Pelayanan Terpadu Satu Pintu (One Gate/One Stop Service) provided by some government agencies (BKPM, BPN, Ministry of Environment and Forestry, etc.), the application of licenses and/or other documents are simpler, easier, and less vulnerable to bribery.

On one hand, such support from Government will help Business actors to grow and sustain their business in Indonesia. On the other hand, the success of business in Indonesia will increase Government income via tax, customs, etc., which will result in public prosperity.

In summary, integrated support from Government and Business actors in improving Indonesia's business environment will result in mutual benefit.

\section{ANTI-BRIBERY OMPLIANCE AS ONE OF THE GOOD CORPORATE GOVERNANCE TO BE APPLIED BY MULTINATIONAL COMPANIES IN INDONESIA}

Good Corporate Governance (GCG) plays important role in improving business environment in Indonesia. The principle of GCG in Indonesia, if we refer to Surat Edaran Bank Indonesia (Circular Letter of Bank of Indonesia) are Transparency, Accountability, Responsibility, Independency, and Fairness.
Although this principle was established by Bank Indonesia, it's also adopted and implemented by Indonesian State-Owned Enterprise or "BUMN" through the Regulation of Minister of BUMN.

The regulation of GCG can be found mainly in 2 laws, which are:

\section{i. Law No. 5/2014 on Civil State} Apparatus

\section{ii. Law No. 30/2014 on Government Administration}

Until now, the implementation of GCG in Indonesia is compulsory for BUMN, Bank, and Public Company, while there is no regulation or obligation to implement GCG for Multinational Companies ("MNCs") in Indonesia.

Despite the absence of such regulation and obligation, MNCs in Indonesia have to adopt and implement policies, including GCG, in their Mother Companies.

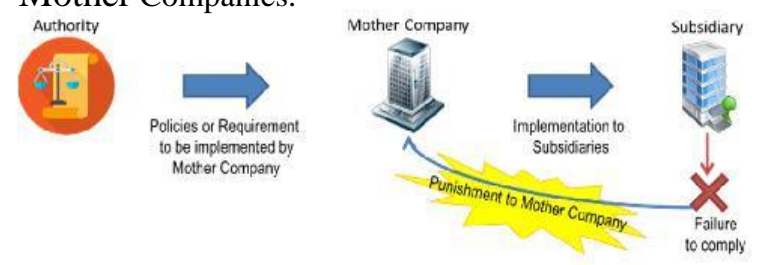

As shown on the illustration, the authority issues policies or requirements to be implemented by the Mother Company. Some of those policies or requirement may have extraterritorial scope, which result in implementation of such policies of requirements to their subsidiaries.

If one or more of the subsidiaries fail to comply with the policies or requirements, the Mother Company will be punished for what its subsidiaries done. Nevertheless, the subsidiary will also be punished by its local government, if it is also against the local law. Therefore, if the Mother Company requires GCG to be implemented, the Subsidiaries shall also implement the same. 
There are some regulations that contain the common principles of GCG and applies extraterritorial. Some

regulation even obliged a company to implement and enforce them to a company's subsidiaries.

Here we have some examples of such regulation, that we generate from US Security and Exchange Commission (SEC) Rule, ${ }^{3}$ which are:

\section{$\checkmark$ Sarbanes-Oxley (SOX) Compliance \\ $\checkmark$ Implementation of Corporate Governance Guideline \\ $\checkmark$ Implementation of Code of Business Conduct and Ethics}

(Including Anti-Competition, whistleblowing procedures, etc.)

\section{$\checkmark$ Cyber security controls $\checkmark$ Anti-Bribery Compliance $\checkmark$ etc.}

Talking about Anti-Bribery Compliance, there are two main regulations that global company todays need to be aware of. The first one is the US Foreign Corrupt Practice Act (FCPA) and the second one is the UK AntiBribery Act.

They're considered "the main" because they're not only the oldest, but they're also the strongest, because they have near-universal jurisdiction. These regulations allow prosecution of an individual or a company who meets their criteria, regardless where the crime happened. They also have investigation team that works cross-borders and even make joint investigation with local governments worldwide. Therefore, basically the enforcement of these two are really strong.

Even if you compare to international convention, for example OECD Anti-Bribery Convention, until now, there are only 49 countries signing the convention, and it won't $100 \%$ bind and enforce the signing countries unless it is adopted to their local regulations.
FCPA was first established in 1977, and has been amended twice. The last amendment was on 1998, in regards to adopting OECD AntiBribery Convention.

This law applies to:

i. "Issuers" of shares, negotiable instruments, investment contracts, in US. It doesn't apply only to the issuers, but also the subsidiaries and/or any part of business that they have. It surely involves a lot of countries here in this criteria, considering that New York Stock Exchange is the largest stock exchange in the world. Not to mention other stock exchanges that the US has.

ii. "Domestic" (nationals, residents, or business entity organized under US Law). It is of course included when we have cooperation with US "Domestics"

iii. Non-issuer and non-domestic but commits acts of bribery in US territory. We can see how wide the scope of the jurisdiction here, considering that there are so many companies either investing in US (both directly and through capital market), or having any cooperation with US company.

The second one is the UK Bribery Act 2010. This regulation has repealed the common law offence of the bribery and the 1889, 1906, and 1916 Acts.

UK Bribery Act 2010 has wider scope of prohibition than any Anti-Bribery regulations, including FCPA. The scope of prohibition doesn't only cover relationship with public officers but also with fellow private companies.

It applies to:

i. Nationals or residents in UK;

ii. Corporation/business entity established or organized under UK Law; and

iii. Foreign companies having business or part of business in UK.

Other things about UK Anti-Bribery Act is that it can impose unlimited fine. It also adopts Strict Liability principle when it comes to Company responsibility.

Therefore, it's not surprising if these two are categorized as the main regulations that should be taken serious attention and actions by global companies, especially those who have direct or indirect business link with US and UK. 
Indonesia has close connection with US and UK. US and England (as part of UK) are in the top 10 of Indonesian investors, based on recent data from BKPM. Furthermore, other countries investing in Indonesia are also investing both directly or indirectly in US. In addition, one of Indonesian State-Owned Enterprise is listed in NY Stock Exchange, which is Telkom. Which means, FCPA also applies to them.

Therefore, we can say that most of MNCs in Indonesia needs to comply with either FCPA, UK AntiBribery Act, or both of them.

There are mainly 4 regulations in Indonesia that regulates

Anti-Bribery matters:

i. Law No. 11 of 1980 on the Criminal Act of Bribery

ii. Law No. 31 of 1999 on the Eradication of Criminal Act of Corruption

iii. Law No. 20 of 2001 on Amendment to Law No. 31 of 1999 on the Eradication of Criminal Act of Corruption; and

iv. Supreme Court Regulation No. 13 of 2016 on Guidance on Handling Corporate Crime.

Summary of Indonesian regulations related with Anti-Bribery:

\begin{tabular}{|c|c|c|c|}
\hline GIVER (ACTIVE) & RECEIVER (PASSIVE) & $\begin{array}{c}\text { INDONESIA } \\
\text { REGULATION }\end{array}$ & $\begin{array}{c}\text { FCPA \& UK ANTI- } \\
\text { BRIBERYACT }\end{array}$ \\
\hline Private & Public Official & PROHIBITED & PROHIBITED \\
\hline Public Official & Public Official & PROHIBITED & PROHIBITED \\
\hline Public Official & Private & Unregulated & PROHIBITED \\
\hline Private & Privale & Unregulated & PROHIBITED \\
\hline
\end{tabular}

We can see from the table above that AntiBribery

Regulation in Indonesia is narrower that FCPA and UK Anti-Bribery Act. It doesn't constitute as the act of bribery if the receiver is not Public Official. However, as mentioned before, MNCs shall comply to FCPA \& UK Anti-Bribery Act if the Mother Company does. Therefore, the scope of application of FCPA and UK Anti-Bribery Act also applies to them.

These are some example of cases where FCPA and UK Anti-Bribery Act were applied to MNCs, including their subsidiaries, taken from the website of US Department of Justice

II.a. Alstom SA (France)
The first case is Alstom, a French companies having subsidiaries around the world, including US, UK, and Indonesia.

Alstom's subsidiaries, Alstom Prom, Alstom Power and Alstom Grid, bribed government officials and falsified books and records in connection with power, grid and transportation projects for state-owned entities around the world.

The mother company was being charged for:

i. failure to voluntarily disclose the misconduct even though it was aware of related misconduct;

ii. refusal to fully cooperate with the department's investigation for several years; and

iii. lack of an effective compliance and ethics program at the time of the conduct.

At the end, US Department of Justice charged Alstom SA USD 772million penalty, while UK SFO and other local authorities impose sanction to Alstom executives and the bribed public officials, including Emir Moeis, who's being charged 3 years imprisonment. $^{5}$

\section{II.b. Marubeni Corporation (Japan)}

The second case is Marubeni Corporation, a Japan Company. Just like Alstom, Marubeni Corp. Japan was responsible for the crime done by its subsidiaries, one of them is Indonesia.

Marubeni, in cooperation with a company from Connecticut US, bribe Indonesian Government in 2014. For that, Marubeni was charge USD 88 million by US Department of Justice. ${ }^{6}$

\section{II.c. Rolls Royce Holding Plc. (UK)}

The last but not the least is the example from Rolls Royce Holding plc., a British company. It has bribed from 2000 to 2013 through its subsidiaries in many countries, including Indonesia. For this case, US DOJ, together with UK SFO and Brazilian authorities, conducted joint investigation for this case, and separately impose sanction to Rolls Royce as shown in the slide.

The difference between this case and Alstom and Marubeni is that Rolls-Royce did not bribe Indonesian public officer. It only bribed Mr. Emirsyah Satar, the president director of PT Garuda Indonesia, which is a private business actor. ${ }^{7}$

From these 3 cases, we can see how strong the enforcement of FCPA and UK Anti-Bribery Act is around the world. 


\section{BOARD OF DIRECTORS AND COMPANY RESPONSIBILITY ON ANTI-BRIBERY COMPLIANCE FOR MULTINATIONAL COMPANIES IN INDONESIA}

\section{III.a. BOD and Company Responsibility}

The Board of Director has the responsibility to ensure

Anti-Bribery Compliance in the Company under Company Law No. 40 of 2007 (“Company Law”). As mainly stated in

Article 97 of the Company Law, the BOD shall be responsible for the management of the company and such management shall be done in good faith and full responsibility.

Such liability extend where the Member of BOD are at fault or negligent in performing their duties. However, it can be excluded if the BOD can prove good faith and preventive measures against the losses.

In terms of Anti-Bribery, the BOD is liable to ensure that the business is running clean, without bribery, and that they have taken all necessary measures to prevent the employees for doing bribery. If they fail to do so, that shall be considered responsible for the bribery done by their employees.

The liability isn't only borne by the member of BOD but also the Company itself as a legal subject.

The Government recently issues the Supreme Court Regulation No. 13 of 2016 on Guidance on Handling Corporate Criminals or "PERMA 13/2016" which can punish Company as a subject for doing criminals, including breaching Anti-Bribery regulations.

This new regulation is a hot issue among Business actors nowadays, considering the breakthrough the Government made. There are some points we need to pay attention at. The first is that this regulation applies only to Limited

Liability Companies or Perseroan Terbatas in Indonesia. The scope of "crime" regulated here is basically all crime that may

be conducted on behalf of the Company. There are also requirement to punish the Company as a subject of crime, which are:

a. Company may benefit or it benefits from such crime, or such crime was done for the benefit of the Company; b. Company allows such criminal act; or

c. Company did not take necessary steps to prevent the crime, or to prevent larger impact, or to ensure compliance to applicable laws to avoid such criminal acts.

The Company's responsibility under said PERMA $13 / 2016$ is in line with the FCPA and UK Anti-Bribery Act. In FCPA, it adopts the Vicarious Liability, where Company is responsible for bribery done by its employees in their work relationship or scope of job.

This kind of liability is the same as the one adopted by PERMA 13/2016, where Indonesian PT shall be liable if the bribery is done to benefit the Company, or was allowed by the Company, or was not prevented by the Company.

While UK Anti-Bribery Act adopts stronger liability, which is the Strict Liability principle. Based on this principle, the Company is responsible for failing to prevent bribery done by its employee, at all cost. Which means, even if the Company has no intention, has no idea, nor benefit from the bribery done by its employee, it shall be liable for it.

However, both liability from these two regulations can be excluded if the Company can prove its good faith and that they have taken necessary preventive measures against Bribery.

\section{III.b. Anti-Bribery Compliance Activity for MNCs}

Board of Directors shall implement Anti-Bribery Compliance activities to ensure comprehensive understanding and enforcement in their Company. If this obligation come up from the Shareholders or Articles of Association, Board of Director should comply as part of the Fiduciary Duties.

Here are some examples of what can be done by the Board of Directors to prove their good faith in managing their Company.

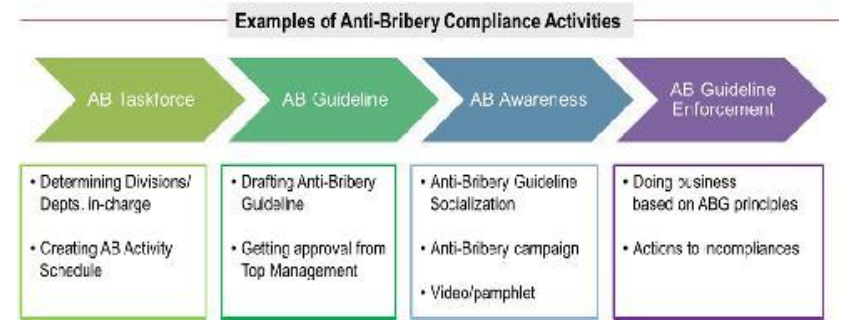

The first one is determining WHO shall be responsible for the enforcement of Anti-Bribery Compliance in the Company. It can be done by establishing an Anti-Bribery Taskforce consisting of 
Legal, or some different Divisions or Departments joined together.

After that, the taskforce itself determine their activity and schedule, which one of them is establishing AntiBribery Guideline. After the AB Guideline was made and approved by the top management, it has to be socialized through a series of Anti-Bribery Awareness activities, such as presentation, campaign, video/pamphlet, interactive discussion, etc.

Finally, the Anti-Bribery Guideline Enforcement shall be taken seriously, starting from doing business based on the Guideline, until taking actions on any violation of it.

Not only the BOD, the Company as a subject also has to prepare itself in preventing any bribery allegation and having the right treatment when it happens.

Examples of preventive actions are:

$\checkmark$ Conduct due diligence to vendor/supplier prior to cooperation $\rightarrow$ We have to be sure that we don't have

anyrelationshiporcooperationwith

Companies/persons that don't have the same spirit

$\checkmark$ Insert Anti-Bribery/Corruption Obligations in every agreement with counterparties $\rightarrow$ As a prove that we do not tolerate any bribery in every cooperation

$\checkmark$ Preserve documentation on Anti-Bribery Compliance activities done by Company

Keep relevant documents for 12 years (due to case expiration period or "Masa Daluwarsa")

While examples of the treatment when bribery has already been done by its employee are:

$\checkmark \quad$ Establish an internal investigation team

Suspend the alleged employee during investigation process

$\checkmark$ Do not let the alleged employee to resign $\rightarrow$ To prevent the removal or hiding of evidence

$\checkmark$ If the crime is proven, terminate the work contract with the employee (subject to CLA / "PKB")

\section{CONCLUSION}

1. Considering that most of MNC in Indonesia have close connection, whether directly or indirectly with US and UK, they have to comply with Anti-Bribery regulations under FCPA and UK Anti-Bribery Act; and

2. The Board of Directors and the Company itself plays important role and holds responsibility in the enforcement of Anti-Bribery Compliance.

\section{REFERENCES}

\section{$\underline{\text { Books }}$}

[1] Maria, Titi, Liability Aspects of Corporate Group Structures, PT. Tata Nusa, Jakarta Indonesia, 2004;

[2] Marbun, Rocky, Kamus Hukum Lengkap, Visi Media, Jakarta Indonesia, 2012;

[3] Triwulan, Titik and Ismu Gunadi Widodo, Hukum Tata Usaha Negara dan Hukum Acara Peradilan Tata Usaha Negara Indonesia, Kencana Prenadamedia Grup, Jakarta, Indonesia, 2011;

[4] Wibawa, Samodra, Reformasi Administrasi, Gava Media, Jogjakarta Indonesia, 2005;

\section{Other Documents}

[5] Bond, Monica, Bribery Act - Strategy and Implementation, Hong Kong Euromoney Legal Training 19-21 May 2014

[6] CNN Indonesia website, https://www.cnnindonesia.com/; KPK website, https://kpk.go.id/;

[7] Transparency International website: https://www.transparency.org/;

[8] US Department of Justice Website: https://www.justice.gov; US Security and Exchange Commission (SEC) Rule 10A-3(b) (3); Wikipedia, http://id.wikipedia.org/; 